\title{
Working memory, metacognition and foreign language reading comprehension: a bibliographical review
}

\author{
Memória de trabalho, metacognição e compreensão leitora em língua estrangeira: uma revisão bibliográfica \\ Memoria de trabajo, metacognición y comprensión lectora en lengua extranjera: una revisión bibliográfica \\ Sidnei Werner Woelfer ${ }^{1}$ \\ Lêda Maria Braga Tomitch ${ }^{1}{ }^{1}$ \\ Leonilda Procailo ${ }^{2}$ \\ 1 Universidade Federal de Santa Catarina (UFSC), Florianópolis, SC, Brasil. \\ 2Universidade Estadual do Centro-Oeste (UNICENTRO), Guarapuava, PR, Brasil
}

$\diamond$

\begin{abstract}
Making sense of texts from a cognitive-processing perspective involves several mental operations connecting conceptual and procedural knowledge (Gagné et al., 1993). In this regard, the reader's ability to articulate several processes simultaneously, involving information processing and comprehension monitoring, is crucial to the construction of the mental representation of texts. Thus, this bibliographical review intends to establish theoretical relationships among reading processing, as sustained by working memory (WM) and influenced by working memory capacity (WMC), metacognition and the componential processes inherent to FL reading comprehension. The implications of the findings point to the relation of metacognition developing according to WM maturation and having an impact on reading comprehension. Therefore, as reading in a foreign language involves more complex activities and the activity per se also involves and depends upon several other variables, it is reasonable to assert that this complex activity is affected by the limitations of WM.
\end{abstract}

Keywords: Working memory. Reading processing. Foreign language reading. Metacognition.

\section{RESUMO}

A construção de sentido em leitura na perspectiva do processamento cognitivo pressupõe uma gama de operações que conectam o conhecimento conceitual e o procedural (Gagné et al., 1993). Assim, a habilidade do leitor em articular vários processos simultaneamente, incluindo o processamento de informações e o monitoramento da compreensão, é crucial para a construção da representação mental de um texto. A presente revisão bibliográfica objetiva traçar discussões teóricas acerca da relação entre o processamento da leitura, sustentada pela memória de trabalho (MT) e mediada pela capacidade de memória de trabalho (CMT), metacognição e os processos componenciais inerentes à compreensão. Conclui-se que há uma relação entre a maturação da MT e o desenvolvimento da metacognição, o que influencia a compreensão leitora. Portanto, como a leitura em língua estrangeira é uma tarefa mais complexa e que também envolve e depende de outras variáveis, consideramos que essa atividade é afetada pelas limitações da MT. Palavras-chave: Memória de trabalho. Processamento em leitura. Leitura em língua estrangeira. Metacognição.

\section{RESUMEN}

La construcción del sentido en la lectura desde la perspectiva del procesamiento cognitivo presupone una serie de operaciones que conectan los conocimientos conceptual y procedimental (Gagné et al., 1993). Así, la capacidad del lector para articular varios procesos simultáneamente, incluyendo el procesamiento de la información y el monitoreo de la comprensión, es crucial para la construcción de la representación mental de un texto. Esta revisión bibliográfica tiene como objetivo esbozar discusiones teóricas sobre la relación entre el procesamiento de la lectura, apoyada en la memoria de trabajo (MT) y mediada por la capacidad de memoria de trabajo (CMT), la metacognición y los procesos componenciales inherentes a la comprensión. Se concluye que existe una relación entre la maduración de la MT y el desarrollo de la metacognición, lo que influye en la comprensión lectora. Por lo tanto, como leer en una lengua extranjera es una tarea más compleja y que también implica y depende de otras variables, consideramos que esta actividad se ve afectada por las limitaciones de MT.

Palabras clave: Memoria de trabajo. Procesamiento en lectura. Lectura en lengua extranjera. Metacognición. 
Reading comprehension, from a cognitive-processing perspective, can be described as involving a large array of mental operations that intertwines readers' conceptual and procedural knowledge, thus enabling them to make sense of texts. As explained by Gagné, Yekovich, and Yekovich (1993), this array of mental operations includes the componential processes of decoding, literal comprehension, inferential comprehension and comprehension monitoring.

Comprehension monitoring is related to readers' control over their own reading process (GAGNÉ et al., 1993; TOMITCH, 2014, among others). For Gagné et al., comprehension monitoring includes the subprocesses of goal-setting, strategy selection, goal-checking, and strategy remediation. Based on that, it can be stated that reading comprehension, besides involving information processing, also involves the reader's metacognitive engagement as reading proceeds. Otherwise stated, metacognition serves as a rudder that steers readers' control over the construction of a successful mental representation of the text and thus to successful comprehension and retention of the information being read.

Hence, important to the construction of this mental representation is the readers' ability to articulate several processes simultaneously, in real time, involving information processing and comprehension monitoring. For Komori (2016) "Monitoring is an executive function of working memory that serves to update novel information, focusing attention on task-relevant targets, and eliminating task-irrelevant noise" (p. 1).

Taking all of the above into account, it can be asserted that working memory capacity (WMC) is critical to successful reading comprehension. Working memory, as defined by Trevisol and Tomitch (2017), can be seen as part of the human cognitive system which is responsible for the temporary and simultaneous storage and manipulation of information understood as necessary for a wide range of complex cognitive activities, such as comprehension, reasoning, and problem-solving, among others (p. 40).

Additionally, several studies have demonstrated that WMC plays a crucial role in language processing. In recent studies, WMC has been correlated with attention to form and meaning in English as a foreign language ${ }^{1}$ (EFL) reading comprehension (BAILER; TOMITCH; D'ELY, 2013), dual-coding of verbal and pictorial information in EFL reading comprehension (WOELFER, 2016), mental translation and comprehension monitoring in $\mathrm{FL} / \mathrm{L} 2$ reading comprehension (ALVES OLIVEIRA,

\footnotetext{
In this study foreign language (FL) is being used interchangeably with second language (SL/L2).
}

2016), and on inference generation and other strategic processes in the (EFL) reading of digital linear and nonlinear hypertexts (PROCAILO, 2017).

Thus, in what concerns the scope of investigation of this bibliographical review, we intend to establish theoretical relationships among reading processing, as sustained by WM and influenced by WMC, metacognition and the componential processes inherent to FL reading comprehension. More specifically, we aim to: 1) Describe and elaborate on two pre-selected influential WM Models; 2) Describe and elaborate on the concept of Metacognition; 3) Identify whether, implicitly or explicitly, the two WM models incorporate accounts on the relationships between WM and Metacognition; 4) Unveil what would be the implications of individual differences in WMC to metacognition and consequently to foreign language (FL) reading comprehension.

The paper is organized into four main subsections, being the first, on WM, the second, on metacognition, the third, on the relationship between them, and the last section brings the final remarks on the main issues discussed in the paper.

\section{Review of the literature on working memory}

Two are the WM models contemplated in this review: (i) Cowan's Embedded Processes Model of WM (1993; 1999; 2015); and (ii) Baddeley's Multicomponent Model of $W M(2010 ; 2015)$. The choice for these two models was made on the basis of their unquestionable influence among studies in the field of language and cognition. Distinct stances of these models on the interaction between WM and long-term memory (LTM $)^{2}$ were also reasons for such a choice, especially if one conceives metacognition as being part of people's more permanent schemata brought into real-time processing while complex cognitive tasks such as FL reading are in execution.

\subsection{The Embedded Processes Model of Working Memory}

Consonant with Cowan's Embedded Processes Model, WM can be operationalized as a set of overlapping processes that, during the conduction of tasks with mental

\footnotetext{
Long-Term Memory (LTM) refers to the relatively stable and long-lasting portion of knowledge stored in memory that is consisted of: (a) knowledge whose meaningfulness is rooted and dependent on associations that are made with specific episodic experiences undergone by individuals (i.e. episodic memory); (b) knowledge whose meaningfulness is purely conceptual, generic and autonomous from specific episodic experiences (i.e. semantic memory); and (c) knowledge that encompasses expertise on how to perform a wide range of activities (i.e. procedural knowledge) (SEALERMAN; HERRMANN, 1994; BADDELEY, 2001).
} 
components (COWAN, 1999), and under the control of a central executive: (a) binds habituated or novel information to already crystallized knowledge of LTM, respectively strengthening, modifying and enriching old mental representations, or forming new ones; (b) activates a non-measurable amount of relevant LTM schemata web according to their relevance in relation to the task at hand; and (c) processes a limited subset of this nonmeasurable amount of activated information, which actually composes the very core of what is the focus of attention.

For Cowan, (1999) the term attention can be understood as "an enhancement of the processing of some information to the exclusion of other, concurrently available information" (p.63). According to the model, information activated below the threshold may remain within WM, but out of the focus of attention.

Overall, Cowan proposes a unitary view of the WM system since it puts a higher emphasis on the relationships among distinct parts of LTM, which, as triggered by a stimulus, are simultaneously activated or left readily available for further activation (COWAN, 2014). Broadly speaking, the researcher considers short-term memory $(\mathrm{STM})^{3}$ as part of WM and defines LTM as the source and passing way of information to be processed in WM (COWAN, 2008a). His emphasis, rather than in separate and individual components such as does Allan Baddeley (see more details in the next section), concentrates on embedded processes that, even varying in terms of levels of activation, are seen as an all-together body of parallel operations serving WM in the processing of highly elaborated cognitive tasks (e.g. FL reading comprehension). As affirms Cowan (2008b), his model conceives Baddeley's separate components as a collection of "temporarily activated portions of long-term memory" (p. 1015), however, it also acknowledges that memory traces originated from the processing of information provided in different modalities may be, indeed, differently represented in memory as well as widely distributed in different parts of the brain. In spite of that, Cowan does not propose the WM modularity defended by Baddeley once, for him, that modularity appears not to fulfill a more complete taxonomy for the processing and maintenance of information derived from other types of sensorial stimuli such as, smell, taste, and touch, for

\footnotetext{
3 According to Cowan (2008a), short-term memory (STM) refers to "faculties of the human mind that can hold a limited amount of information in a very accessible state temporarily (...) It is possible that not very temporarily accessible idea is, or even was, in conscious awareness. For example, by this conception, if you are speaking to a person with a foreign accent and inadvertently alter your speech to match the foreign speaker's accent, you are influenced by what was until that point an unconscious (and therefore uncontrollable) aspect of your shortterm memory" (p.324-325).
}

instance (COWAN, 2014). As claimed by Cowan (1999; $2008 \mathrm{~b}$ ), what the model proposes is that independently of format and their origins in distinct parts of the brain, these memory traces are features that, processed in an analogous, but not necessarily equal manner, make LTM, both the source and the beneficiary of the WM products (COWAN, 1993; COWAN, 2015).

With that in mind, Cowan (1999) proposes distinct accounts to explain his model when it comes to WM limitations. Initially, he explains how the model conceives the limitations of the activated portion of WM and secondly, the limitations of the focus of attention.

First of all, Cowan questions any attempt to quantify individuals' the total capacity of WM activation. Taken that as truth, individuals would not necessarily perform differently in cognitive tasks because they differ in the total amount of cognitive resources they have available for processing and maintenance of information, but because they differ in the task of bringing relevant information from LTM into the focus of attention. This scenario changes concerning time limits. As argued by Cowan (1999), the activated portion of the information that is linked to the smaller portion under the focus of attention 'wanes', as put by the author, or diminishes, as time passes by. In simpler words, the model proposes that the disuse of readily available information leads to its deactivation, and that appears to be easily comprehensible if one considers the dynamics of WM real-time processing: information in the focus of attention changes so as to match what the core of the processing in each distinct moment is.

In addition, Cowan (1999) contends that individuals perform better when focusing on singular schemes "at a particular moment, not on many unrelated items or schemes" (p.85), especially because research has found pieces of evidence that the number of chunks of information that can be held at the same time under the focus of attention is limited (COWAN, 2008a). Yet, in relation to time limits, the unique limitation Cowan points out is that the focus of attention on specific pieces of information cannot be in a never-ending maximum activation level because one's state of alertness lessens along the time. In fact, a never-ending state of alertness on a singular piece of information would not be actually possible, again, due to the dynamics of the WM operations because individuals go on changing their focus of attention according to contextual needs, as the task at hand is carried out.

\subsection{The Multicomponent Model of Working Memory}

Important changes have marked the development of the Multicomponent Model of Working Memory (M-WM) 
since its very first assumptions by Baddeley and Hitch in 1974 were made.

As opposed to Cowan's top-down approach of WM in which LTM is assumed to play a central role in the processes under the focus of attention in WM, Baddeley's bottom-up approach tries to offer more sequential stepby-step accounts to what this mind faculty actually is believed to encompass (BADDELEY, 2012).

To start with, Baddeley (2010) describes WM as "the system or systems that are assumed to be necessary in order to keep things in mind while performing complex tasks such as reasoning, comprehension and learning" (p. 136). By the same token, his proposal is of a system theoretically subdivided into separate and specialized components that enable people to mentally represent the immediate past and present world events so that new knowledge can be constructed, problems solved, goals formulated and attempted to be achieved (BADDELEY; LOGIE, 1999). In essence, Baddeley opts to guide his rationale following a more structural view of WM, an option partly influenced by results obtained through behavioral studies conducted by him, colleagues and by other researchers in the area, and partly influenced by neurobiological studies that seemed to suggest that WM depends on various brain regions for its effective functioning.

As described by Baddeley, himself, $(2010 ; 2012)$ and Baddeley and Logie (1999), WM comprises a supervisory system, namely central executive (CE) responsible for: (a) focusing attention on tasks being carried out in real time; (b) sharing attention between concurrent tasks; (c) switching of attention from one task to another; and (d) interfacing WM and LTM. No storage functions are attributed to this so-called 'homunculus' (BADDELEY; LOGIE, 1999) whose main function is to manage at least three slave subsystems, namely the phonological loop (PL), the visual-spatial sketchpad (VSSP) and the episodic buffer (EB) (BADDELEY, 2010; 2012), each of them having independent limited amount of cognitive resources to maintain information in an activated state.

The first and most widely investigated subsystem, the PL, is pointed out as being responsible for the momentary storage and active rehearsal of speech-like memory traces originated from the sensorial caption of verbal information. The momentary storage or verbal memory traces would be a function of a passive PL phonological store, whereas the active processing of these traces, a function of rehearsal processes. The subsystem, as just mentioned, is assumed to be limited in its capacity to maintain information in an activated state within WM, and to have its operations influenced by information retrieved from LTM and perception. For the purposes of this review, this is one of the most important subsystems to be considered since it speaks directly to FL reading comprehension, as it will be explained later in the text.

The VSSP, according to this model, is described as a slave subsystem whose function is to store and rehearse memory traces derived from the sensorial caption of dimensions, colors, forms and other visual-spatial-like pieces of information found in the environment. As fractionated by Logie (1995) and mentioned in Baddeley and Logie (1999), the inner scribe is assumed to be the VSSP subcomponent in charge of retaining spatial-like memory traces whereas the visual cache, in charge of executing the same function regarding visual-like memory traces. As well as the PL, the VSSP is also assumed to be a limited capacity subsystem that is interconnected with LTM and perception.

Lastly, the EB is described as being responsible for the storage of multi-coded information assumed to be bound into chunks by the CE (BADDELEY, 2012). It is considered a passive store that allows for the allocation of multidimensional mental representations possibly including memory traces derived from the processing of other senses such as smell and taste, for instance. This slave system has been shown to hold around 4 simultaneous objects and also as being interconnected with LTM and perception, as well.

All in all, the four WM components described above, as proposed by Baddeley (2010), are considered fluid systems due to their function to temporarily control the flow of information into and out of long-term memory" (p.137). Now, LTM is seen as a permanent and crystallized system whereby a complex web of schemata individuals built up in a lifetime are assessed in order to make sense of novel information captured via perception.

Overall, it is possible to conclude that Baddeley proposes more discrete subdivisions among the distinct parts of his model than does Cowan in relation to The Embedded Processes Model of Working Memory, and this seems to be the main difference between the accounts offered by them. In spite of Baddeley's (2012) statement that his and Cowan's models differ only in terms of terminology and emphasis, it is noticeable that Baddeley defends the influence of LTM on WM, being the first and the second totally independent systems (BADDELEY; LOGIE, 1999). As opposed to that, Cowan, rather than proposing discrete borders between separate systems, advocates for overlapping processes that vary in terms of levels of activation. Thus, we may assert that his model does not propose separate fluid and crystallized systems, but a unique fluid system in which WM is assumed to be embedded within LTM, comprising an activated portion of LTM information and a subset of this information kept in the focus of attention. 


\section{On metacognition}

Metacognition, a topic that according to Baker and Beall (2009) has been under the focus of research for approximately forty years since John Flavell and Ann Brown's seminal works in the 70's were published, can, in a very broad sense, be characterized as a set of cognitive processes one makes aware use of in order to monitor and/or foster his/her own mental operations. Having its very beginning with the works of Piaget and Flavell in developmental psychology (VEENMAN, 2015), and being distinct from cognitive skills, metacognition, as pointed out by Bondy (1984), is not always an entirely automatized set of processes resulting from subject expertise. As opposed to that, depending on the level of difficulty of the task at hand, even experts have to engage into more careful regulations over their own mental operations so that hampering events that may disrupt processing and the implementation of certain tasks can be properly identified and strategies used. When it comes to reading, however, mention should be made to what states Baker and Brown (1984), Gagné, Yekowich and Yekowich (1993) and Baker and Beall (2009) in that age and skillfulness tend to lead to the faster and more automatic use of metacognition.

As defined by Afflerbach, Pearson, and Paris (2008), skills and strategies differ in that the first can be considered automatic processes and the latter, "deliberately controlled processes" (p.371). Coupled with that, it is intentionality that differentiates these two cognitive abilities; while skills are already-automatized strategies, strategies, if in effective and continuous use, are skills in the process of development, or skills already acquired, but in a stage of deautomatization due to the appearance of unexpected reading comprehension occurrence (MANOLI; PAPADOPOULOU, 2012).

The importance of differentiating skills from strategies resides in the assertion that metacognitive readers are those who are able to orchestrate a wide range of processes while reading, so this reading can be effective. Be this orchestration made by means of totally aware, controlled and goal-oriented strategies, or be it naturally conducted by automatized skills that are brought into action with no aware effort, the ultimate goal of their operations in reading is to allow readers to go beyond the levels of decoding and literal comprehension, so that they can dive into more profound reading adventures only inferential comprehension allows. Or, as explained by Bondy (1984), well-developed metacognitive skills are extremely important to all human beings given the challenge that lifetime situations in which planning, acting, remediating and solving acts to the achievement of goals are imposed to them. In other words, individuals who are able to notice, evaluate and understand the status of his/her own mental operations more likely optimize them in precise moments and, thus, succeed in the accomplishment of tasks.

Now, concerning L1 reading, Baker and Brown (1984) offer rich contributions to the above-reported elaborations. By posing that metacognition, within a more interactive view of reading (RUMELHART, 1980; 1981) involves continuous "hypotheses testing or schema building" (p.355), the authors bring to the fore the assumption that effective reading comprehension tends to be more successfully achieved when readers constantly evaluate whether reading predictions are being met or not. Thus, the analogy proposed by Rumelhart (1984) is welcomed in that readers act such as detectives who try to make sense of all possible available information in order to unravel and make sense of things. Similarly, metacognition involves one's careful regulation over his/her own understanding that better guarantees a balance between two extremes that may take place while reading is being carried out: mere decoding that is likely to lead readers to poor comprehension, or overreliance on top-down reading processes that are likely to lead them to 'the illusion of knowing' proposed by Elpstein, Glenberg and Bradley's ( as cited in TOMITCH, 1995), when readers feel they have understood a piece of written discourse, when they actually have not. In Veenman's (2015) words, that would refer to readers' overestimating of "competences, relative to the subjectively perceived task complexity" (p.27). Having that in mind, it is possible to assert that metacognition is the key element that allows one to perceive his/her own real interaction with the text during reading and, thus, to be able to respond to questions such as: (i) "am I getting what the gist of this text"?; (ii) "am I using proper strategies to pursue the specific goals of this specific reading situation"; a (iii) "am I overseeing important details of the text when just looking for main ideas"?, etc.

More insights on metacognition also come from Gagné's et al. (1993) model of reading comprehension, already mentioned in the introduction of this review. Firstly, as defined by Gagné et al., metacognition encompasses control processes human beings make aware use of when involved in the task of looking for the accomplishment of a goal. At this point, these researchers refer to metacognition as an ability to make use of strategies to effectively carry out any type of daily tasks. Secondly, Gagné and colleagues include metacognition in their chapter on reading and define it as "one's awareness of one's own cognitive processes" (p.279), an idea that matches well Baker and Brown (1984) and Bondy's (1984) above mentioned assumptions.

Consonant with Gagné's et al. (1993) model, metacognition is represented in the comprehension 
monitoring level. Comprehension monitoring comprises four basic subprocesses, namely goal-setting, strategyselection, goal-checking and remediation that, according to these researchers, are spontaneously activated and implemented in a cyclic fashion in proficient reading. Concisely, this set of processes involves the readers' self-perception of their own reading progression, which would relate to Nelson and Naren's (1994) metalevel, as opposed to object level that would include processes executed in decoding, literal comprehension, and inferential comprehension. As a matter of fact, the processes of comprehension monitoring proposed in Gagné et al.'s model can be regarded as the processes that allows one's continuous control over the efficiency of the cognitive operations involved in his/her own reading comprehension.

The first and second subprocesses, goal-setting and strategy-selection are two intrinsically related subprocesses. According to this framework, the first involves one's defining what the main goal of the reading event will be, prior to actually starting it. For instance, the same text can be read to be more profoundly understood for a midterm test, or it can just be read to have some of its topics revised for a group discussion. This self-awareness of the goal is what defines how cognitively engaged with the reading process the reader will be. The latter, strategyselection, is related to the methodical way the reader will carry out his reading in order to meet his/her goals. For instance, $\mathrm{s} /$ he can decide to skim the text initially in order to activate previous knowledge on its main topics to, later on, produce a summary, or if well familiarized with the topic, scan the text straight away to identify its main ideas.

Goal-checking and remediating are, according to this framework, the other two intrinsically related subprocesses inherent to comprehension monitoring. They respectively refer to one's self-control over the achievement of the reading goal initially set, and the use of new strategies to solve possible deficiencies on the expected achievement. For instance, if one's reading goal is getting prepared to deliver a talk on a specific topic of a certain area, but difficulties to verbalize ideas without just reproducing terms found in the original sources are noticed, changes or adaptations on the strategies being used have to be made. This reader, then, may be in need of writing his/her own summaries and elaborations in order to feel more confident to express informed opinions on the topic.

To add to that, Baker and Beall (2009) pose that "the conclusion that remains valid today is that older and more skilled readers demonstrate better comprehension monitoring" (p.786). Such a conclusion grounds the assertion that the automatization of lower-level reading skills allows WM to devote more of its resources to operate comprehension monitoring.
Having all that has been said in relation to $\mathrm{L} 1$ reading in mind, one wonders whether the same principles on metacognition and reading comprehension would be applied to FL reading. The answer, as far as affirms Sparks when specifically referring to English as a foreign language (EFL) reading (2012) is "yes". In fact, it is possible to predict that metacognition plays a paramount role in this realm since automaticity of language processing, depending on the reader's proficiency level, differs a lot from $\mathrm{L} 1$ to EFL reading.

Finally, yet equally important, it is to realize that metacognition, be it in L1 or in FL reading, encompasses a set of strategic processes that can be turned into skills by means of constant strategy use. For this reason, in many of the studies here reviewed, such as in Baker and Brown (1984), Bondy (1984), Gagné et al. (1993), Afflerbach et al. (2008), and more recently, Baker and Beall (2009), Manoli and Papadopoulou,(2012), Matsumoto et al. (2013) and Veenman (2015), researchers have advocated for the teacher's intervention in the form of strategies teaching from early childhood into adolescence because awareness is one of the most important cognitive characteristics that directly serves successful meaning construction (Hagen et al., 2014). All of these researchers, regardless the focus on L1 or on FL reading comprehension, appear to agree that even though teachers have no direct access or control over students' mental processes, they have in their hands the power to create conditions to foster their students' self-awareness development, which, in turn, may lead to successful reading comprehension.

\section{On the relationship between working memory and metacognition}

This section initially introduces our inferences on the relationships between metacognition and the tenets proposed in the Embedded Processes Model of Working Memory. In the sequence, it presents a similar set of inferential conclusions in relation to the tenets of the Multicomponent Model of Working Memory. Finally, it expounds some hypotheses in what concerns the relationships among WM, metacognition and FL Reading Comprehension.

\subsection{Metacognition and the Embedded Processes Model of Working Memory}

Cowan (1999) in his answers to Miyake and Shah's (1999) eight designated questions poses various explanations that serve as a basis to the elaborating on what some of the relationships between WM and metacognition might be. 
Considering all that has been said in this review so far, it can be asserted that metacognition comes into play when FL users are aware of what they are doing, that is, when they have relevant information in the focus of attention and when they identify signals of failure in comprehension processes. Some of such failures, especially applied to nonfluent FL users, may be triggered by their lack of efficient lexical and syntactic processes that will compete for cognitive processing and thus consume more resources in this lower level, leaving little or no resource for higher level processes, such as information integration across sentences for a coherent situation-model construction (ZWAAN; BROWN, 1996). Also, assuming that during comprehension construction higher amounts of information must be simultaneously kept in a highly activated state in WM so that new concepts can be built (COWAN, 2015), the need for monitoring appears to be the very base for the construction of new or expansion of existing knowledge, since, as highlighted by Baker et al. (2014), metacognition encompasses "the awareness and control of one's own cognitive processes" (p.167). Having that in mind, it is more than reasonable to assume that relevant information has to be in the focus of attention, that is, not below the threshold, so that the demands of language tasks can be fulfilled. With no control over cognitive processes, some FL users, for instance, would simply not be able to evaluate relevance, correctness, need for adaptation, remediation, goal changing, etc., while reading.

Research on inference generation has provided solid evidence regarding L1 and L2 comprehension and both proficiency and reading skill are complementary constructs. Regarding L2 comprehension, skilled comprehenders construct stronger text-based representations than less skilled comprehenders, besides, they are more accurate in paraphrasing, that is, translating L2 sentences. In this sense, lower level processing will be prioritized over higher-level ones, thus being more resource consuming during L2 comprehension than during L1 comprehension (ZWAAN; BROWN, 1996).

Besides, as proposed by Cowan (2014), one has to stick to the relevant goals of a given task when it comes to learning. The same can be asserted in relation to FL reading comprehension. In other words, even when individuals present well-developed reading skills, their absence as "observer readers" may lead their boat to veer too far from successful comprehension. Being unaware of the rudder, of the map and of possible ship mechanical problems as reading proceeds, is something that might beach readers in shallow seas of comprehension. Put differently, even though automaticity decreases the need of attention to action due to habituation (COWAN, 2014), a state of awareness better guarantees the arrival at desirable comprehension destinations.
Largely, the Embedded Processes Model of Working Memory posits that there is a continuum of activation among LTM, STM, and WM, all of them contributing to the processing of the task at hand, in the case of this particular review, FL reading comprehension. Thus, it is possible to assert that Cowan's focus of attention would be the portion of WM where metacognitive functions involved in reading (i.e. goal- setting, strategy selection, goal-checking, and remediation) would actually fit. To conclude, if comprehension monitoring demands the reader's awareness to what is going on in the reading process, no big issue seems to exist in asserting that metacognition is associated with the well-known functions of the WM central executive that determines what has to be maintained in the focus of attention and what has not.

\subsection{Metacognition and the Multicomponent Model of Working Memory}

A bit more complex is the task to establish relationships between WM and metacognition within Baddeley's WM framework since at least in the material reviewed, no mention directly made on the importance of metacognition to information processing was found.

Despite one's almost inescapable tendency of attributing metacognitive functions to one of the subsystems proposed by this model simply because, theoretically speaking, the model somehow demands a kind of mental operations inboxing, saying that the CE's functions enclose metacognition is not a refutable thesis. That conjecture could be made because, as discussed by Baddeley (2010), the central executive is "a term that refers to the system whereby working memory is controlled" (p.139), which in turn, as postulated by Baddeley and Logie (1999), is the system that "allows the organism to reflect on the available options and choose particular actions or strategies rather than being driven by the sheer weight of past experience" (p. 53).

Unquestionably, the last citation may be taken as a subtle pinprick to Cowan's stance on what WM actually is, since it suggests that LTM appears not to be so central for every single mental operation executed by WM. That makes sense when totally novel information is encoded during L1 and L2 reading, for instance.

To better understand how metacognition can be associated with the functions of the $\mathrm{CE}$, it is worthy to contemplate what is proposed by Archilla-Suerte et al. (2015). According to the researcher, although attributing different roles to selective attention and WM (i.e. filtering information to the real-time focus of attention and maintaining past information in an activated state for further processing, respectively), "selective attention and working memory are not completely independent 
phenomena" (p.46). This conclusion appears to match well what is defined by Baddeley (2012) as regards the CE's functions, namely, focusing attention, dividing attention between different types of stimulus, switching between concurrent tasks, and interfacing WM with LTM.

Concisely, it seems reasonable to assert that the CE plays a key role in the operation of metacognitive processes, and also that this key role may inform the understanding on the relationships between metacognition and FL reading. As argued by Baddeley and Logie (1999), it is the central executive under the moment-to-moment monitoring the condition that permits interaction among various cognitive processes. Here, it is possible to infer that interaction also occurs among decoding, literal comprehension and inferential comprehension (GAGNÉ et al., 1993) by means of activation and matching of novel and preexisting information into coherent mental models, which in turn are assumed to be consolidated in LTM.

\subsection{Working Memory Capacity, Metacognition and FL Reading Comprehension}

Having departed from a description of two selected WM models (COWAN, 1993, 1999; BADDELEY, 2000; 2015) and then proceeded with a series of inferences on how metacognition would fit these models, we move forward by talking about individual differences in WMC and their effects on the operation of metacognitive processes involved in FL reading comprehension.

According to Cowan (2015), "second language use must involve the coordination of many kinds of information" (p.32). Having in mind that within the realm of FL reading the coordination of many kinds of information such as vocabulary knowledge, word order, and syntactic processing will be more resource consuming than in L1 reading (ZWAAN; BROWN, 1996), those low-level processes will occur at the expense of higher level ones such as inferential comprehension and metacognition.

Based on Gagné et al.'s (1993) model, for instance, verbal information presumably demands WM resources to be actively maintained during decoding, literal comprehension, and inferential comprehension. The development of ideas and the construction of meanings are thus nothing but products of continuous processes that depend on the activation of WM resources. Considering the well-agreed assumption that WM is a system that operates within a limited amount of these resources, attention has to be drawn to what postulates Just and Carpenter (1992), in their capacity-constrained view of WM. According to this view, WM is a system that operates within a budget of resources used for the processing and storage of information and that, "cognitive capacity constrains comprehension, and it constrains more for some people than for others" (p.122). In other words, some people do better when performing highly demanding cognitive tasks such as metacognitive processes because their WM system itself has a larger capacity, defined as the total amount of activation in WM the individual can count on to execute the task at hand.

Considering all the above, it is reasonable to predict that when the commodity, namely activation, is not sufficient for the full implementation of higherlevel reading processes, metacognition, might also be affected. Affected because, if it holds true that within the domain of reading comprehension, monitoring can be regarded as the most important metacognition skill whereby comprehension is regulated and constantly evaluated (BAKER et al., 2014), lower spans will probably tend to struggle while trying to monitor their own reading. Therefore, it might be that having all their resources used for the execution of lower-level reading processes (decoding and literal comprehension), the higher-level processes of inferential comprehension and comprehension monitoring will suffer, being poorly executed or not executed at all.

To what extent low-spans are able to manage comprehension failures, check goals and find fix-up measures is still dependent upon several factors. Well defined reading objectives, for instance, is one of this factors that have to be considered because they help identify irrelevant information that can be suppressed so as to enable them to engage in strategic processing that would demand less from the cognitive system. Previous studies using verbal reports as data have highlighted metacognitive comments as a resource consuming process and the verbalization of those thoughts can be said to split the attention of readers between making meaning and reporting their troubles. Hence, variables such as reading purpose and text mode, as revealed by previous studies, provide evidence of comprehension monitoring during the performance of all tasks by low-spans. (PROCAILO, 2017; LINDERHOLM; VAN DEN BROEK, 2002; VAN DEN BROEK; LORCH; GUSTAFSON, 2001). Several strategies are used to avoid overloading and to optimize the task. That is, when facing several activities which have to be performed simultaneously, low-spans opt not to verbalize the process they are going through, saving resources to other tasks, while high-spans readers tend to utter their difficulties related to vocabulary knowledge, text structure, and constraints related to the integration of ideas (PROCAILO, 2017).

\section{Conclusion}

As postulated by Baker et al. (2014), "executive functions, or higher-order cognitive abilities involved in 
goal-directed behavior, develop throughout childhood into early adulthood" (p. 170). As explains Veenman (2015), such a development accompanies the development of metamemory, at the age of 5 to 6 years, and is underlain by the maturation of executive functions. Thus, human beings start to develop metacognition since very early in life and that development reaches its apogee in late adolescence and early adulthood. Still, according to Baker et al. (2014), "metacognition depends on executive control skills that continue to develop into early adulthood, in parallel with the maturation of the executive control regions of the prefrontal cortex" (p. 167). Concisely, it is a period of life in which reading processes and reading strategies, depending on how one's process of knowledge acquisition occurs, become more and more accurate and may be turned into automated skills that might guarantee higher availability of cognitive resources for deeper levels of processing in reading to take place. Of course, such a perfect prediction may become real in ideal conditions, and even so, it cannot be taken for granted given the many variables emerged from individual differences and from distinct reading contexts.

Finally, the development of WM in the very same period of life seems to explain its possible relationship with metacognition. In other words, metacognition develops according to the maturation and development of WM and it is constrained by WM limitations, which per se, at the end of the story, may affect FL reading comprehension. Nevertheless, we acknowledge that the aforementioned conclusion is not being stated here as absolute truth, but as a possible conjecture of the present review itself with all its inherent limitations.

\section{References}

AFFLERBACH, Peter; PEARSON, P. David; PARIS, Scott G. Clarifying differences between readings kills and reading strategies. The Reading Teacher, Newark, v. 61, n. 5, p. 364-373, 2008. Available in: http://northfieldtownshipschools.pbworks. $\mathrm{com} / \mathrm{f} /$ Difference+between + reading + skills + and + strategies.pdf. Access in: May 26, 2018. https://doi.org/10.1598/RT.61.5.1

ARCHILLA-SUERTE, Pilar; ZEVIN, Jason; HERNANDEZ, Arturo E. The effect of age of acquisition, socioeducational status, and proficiency on the neural processing of second language speech sounds. Brain \& Language, Amsterdam, v. 141, p. 35-49, Feb. 2015. Available in: https://www.ncbi. nlm.nih.gov/pubmed/25528287. Access in: Sept. 1, 2018. https://doi.org/10.1016/j.bandl.2014.11.005

BADDELEY, Alan. The concept of episodic memory. Philosophical Transactions of the Royal Society of London: Series B, Biological Sciences, London, v. 356, n. 1413, p. 1345-1350, Sept. 2001. Available in: https://www.ncbi.nlm. nih.gov/pmc/articles/PMC1088518/. Access in: Apr. 23, 2018. https://doi.org/10.1098/rstb.2001.0957
BADDELEY, Alan. Working memory. Current Biology, London, v. 20, n. 4, p. 136-140, Feb. 2010. Available in: https://www.ncbi.nlm.nih.gov/pubmed/20178752. Access in: June 3, 2018. https://doi.org/10.1016/j.cub.2009.12.014

BADDELEY, Alan. Working memory in second language learning. In: WEN, Zhisheng Edward; MOTA, Mailce Borges; MCNEIL, Arthur (ed.). Working memory in second language acquisition and processing. Bristol: Multilingual Matters, 2015. p. 17-28. https://doi.org/10.21832/ 9781783093595-005

BADDELEY, Alan. Working memory: theories, models, and controversies. Annual Review of Psychology, Palo Alto, v. 63, p. 1-29, 2012). Available in: https://www.annualreviews.org/ doi/pdf/10.1146/annurev-psych-120710-100422. Access in: Jan. 28, 2018.

BADDELEY, Alan; LOGIE, R. H. The multiplecomponent model. In: MIYAKE, Akira; SHAHH, Priti (ed.). Models of working memory: mechanisms of active maintenance and executive control. New York: Cambridge University Press, 1999. p. 28-61. https://doi.org/10.1017/ CBO9781139174909.005

BAILER, Cyntia; TOMITCH, Lêda Maria Braga; D'ELY, Raquel Carolina Souza Ferraz. Working memory capacity and attention to form and meaning. Letras de Hoje, Porto Alegre, v. 48, n. 1, p. 139-147, jan./mar. 2013. Available in: https://pdfs.semanticscholar.org/3389/ e1c0d4565a3e4e5a32dc18746e3e0b8171f7.pdf. Access in: Jul. 15, 2018.

BAKER, Linda; BEALL, Lisa Carter. Metacognitive processes and reading comprehension. In: ISRAEL, Susan E.; DUFFY, Gerald G. (ed.). Handbook of research on reading comprehension. Oxon: Routledge, 2009. p.373-388.

BAKER, Linda; BROWN, A. L. Metacognitive skills and reading. In: PEARSON, P. D. et al (Eds.). Handbook of reading research. New York: Longman, 1984. p. 353-394.

BAKER, Linda; ZELIGER-KANDASAMY, Alisa; DE WYNGAERT, Laura U. Neuroimaging evidence of comprehension monitoring. Psychological Topics, Baltimore, v. 23, n. 1, p. 167-187, 2014. Available in: https://pdfs.semanticscholar.org/d948/ cbafd757680c295c14be2daeac6d1c9be46b.pdf. Access in: Aug. 10, 2018.

BENTON, Stephen L. et al. Cognitive capacity differences among writers. Journal of Educational Psychology, Washington, v. 76, n. 5, p. 820-834, 1984. Available in: http:// psycnet.apa.org/record/1985-10774-001. Access in: Aug. 27, 2018. https://doi.org/10.1037/0022-0663.76.5.820

BONDY, Elizabeth. Encouraging children's use of metacognitive processes: thinking about thinking. Childhood Education, London, v. 60, n. 4, p. 234-38, 1984. Available in: https://www.tandfonline.com/doi/abs/10.1080/00094056.19 84.10520655? journalCode=uced20. Access in: June 3, 2018. https://doi.org/10.1080/00094056.1984.10520655 
COWAN, Nelson. Activation, attention, and short-term memory. Memory \& Cognition, New York, v. 21, n. 2, p. 162-167, Mar. 1993. Available in: https://link.springer. com/article/10.3758/BF03202728. Access in: June 17, 2018. https://doi.org/10.3758/BF03202728

COWAN, Nelson. An embedded-processes model of working memory. In: MIYAKE, Akira; SHAH, Priti (ed.). Models of working memory: mechanisms of active maintenance and executive control. New York: Cambridge University Press, 1999. p. 62-101. https://doi.org/10.1017/ CBO9781139174909.006

COWAN, Nelson. Second language use, theories of working memory and the vennian mind. In: WEN, Zhisheng Edward; MOTA, Mailce Borges; NECNAIL, Arthur. (ed.). Working memory in second language acquisition and processing. Bristol: Multilingual Matters, 2015. p. 224-246. https://doi. org/10.21832/9781783093595-006

COWAN, Nelson. What are the differences between long-term, short-term and working memory? Progress in Brain Research, Amsterdam, p. 323-338, 2008a. Available in: https://www.ncbi. nlm.nih.gov/pmc/articles/PMC2657600/. Access in: Mar. 22, 2018. https://doi.org/10.1016/S0079-6123(07)00020-9

COWAN, Nelson. Working memory. In: SALKIND, Neil J. (ed.). Encyclopedia of educational psychology. London: Sage, 2008b. v. 2, p. 1015-1016.

COWAN, Nelson. Working memory underpins cognitive development, learning and education. Educational Psychology Review, New York, v. 26, n. 2, p. 197-223, June 2014. Available in: https:/www.ncbi.nlm.nih.gov/pmc/articles/ PMC4207727/. Access in: Feb. 23, 2018. https://doi. org/10.1007/s10648-013-9246-y

DANEMAN, Meredyth; CARPENTER, Patricia A. Individual differences in integrating information between and within sentences. Journal of Experimental Psychology: Learning, Memory and Cognition, Washington, v. 9, n. 4, p. 561-584, 1983. https://doi.org/10.1037//0278-7393.9.4.561

DANEMAN, Meredyth; GREEN, Ian. Individual differences in comprehending and producing words in context. Journal of Memory and Language, Amsterdam, v. 25, n. 1, p. 1-18, Feb. 1986. Available in: https://www.sciencedirect.com/science/ article/pii/0749596X86900185. Access in: May 30, 2018. https://doi.org/10.1016/0749-596X(86)90018-5

GAGNÉ, Ellen D.; YEKOVICH Carol Walker; YEKOVICH, Frank R. The cognitive psychology of school learning. New York: Harper Collins, 1993.

HAGEN, Åste M.; BRAASCH, Jason L. G.; BRÅTEN, Ivar. Relationships between spontaneous note-taking, self-reported strategies and comprehension when reading multiple texts indifferent task conditions. Journal of Research in Reading, Hoboken, v. 37, n. S1, p. 141-157, Mar. 2014. Available in: https://doi.org/10.1111/j.1467-9817.2012.01536.x. Access in: June 13, 2018. https://doi.org/10.1111/j.14679817.2012.01536.x
JUST, Marcel A.; CARPENTER, Patricia A. A capacity theory of comprehension: Individual differences in working memory. Psychological Review, Washington, v. 99, n. 1, p. 122-149, 1992. Available in: http://psycnet.apa.org/ record/1992-15357-001. Access in: June 17, 2018. https://doi.org/10.1037//0033-295X.99.1.122

KIEWRA, Kenneth A.; BENTON, Stephen L. The relationship between information-processing ability and notetaking. Contemporary Educational Psychology, Amsterdam, v. 13, n. 1, p. 3-44, Jan. 1988. Available in: https://www.sciencedirect.com/ science/article/pii/0361476X88900045. Access in: May 20, 2018. https://doi.org/10.1016/0361-476X(88)90004-5

KING, Jonathan; JUST, Marcel A. Individual differences in syntactic processing: the role of working memory. Journal of Memory and Language, Amsterdam, v. 30, n. 5, p. 580-602, 1991. Available in: http://psycnet.apa.org/ record/1992-07864-001. Access in: Mar. 13, 2018. https://doi. org/10.1016/0749-596X(91)90027-H

KOMORI, Mie. Effects of working memory capacity on metacognitive monitoring: A study of group differences using a listening span test. Frontiers in Psychology, Brussels, v. 7, p. 1-7, Mar. 2016. Available in: https:/www.ncbi.nlm.nih. gov/pubmed/26973577. Access in: Oct. 1, 2018. https://doi. org/10.3389/fpsyg.2016.00285

LINDERHOLM, Tracy; VAN DEN BROEK, Paul. The effects of reading purpose and working memory capacity on the processing of expository text. Journal of Educational Psychology, Washington, v. 94, n. 4, p. 778-784, 2002. Available in: http://psycnet.apa.org/record/2002-06506-012. Access in: Aug. 10, 2018. https://doi.org/10.1037//0022-0663.94.4.778

LOGIE, Robert H. Visuo-spatial working memory. Hove: Erlbaum, 1995.

MANOLI, Polyxeni; PAPADOPOULOU, Maria. Reading strategies versus reading skills: two faces of the same coin. Procedia: Social and Behavioral Sciences, Amsterdam, v. 46, p. 817-821, 2012. Available in: https://www.sciencedirect. com/science/article/pii/S1877042812013341. Access in: Apr. 28, 2018. https://doi.org/10.1016/j.sbspro.2012.05.205

MATSUMOTO, Hiroyuki; NAKAYAMA, Akira; HIROMORI, Tomohito. Exploring the development of individual difference profiles in L2 reading. System, Amsterdam, v. 41, n. 4, p.994-1005, Dec. 2013. Available in: https://www.sciencedirect.com/science/article/pii/ S0346251X13001243\#!. Access in: Mar. 2, 2018. https://doi. org/10.1016/j.system.2013.09.008

MIYAKE, Akira; SHAHH, Priti (ed.). Models of working memory: mechanisms of active maintenance and executive control. New York: Cambridge University Press, 1999. p. 442481. https://doi.org/10.1017/CBO9781139174909

NELSON, T. O.; NARENS, L. Why investigate metacognition? In: METCALFE, Janet; SHIMAMURA, Arthur P. (ed.). Metacognition: knowing about knowing Cambridge: MIT Press, 1994, p. 1-25. 
OLIVEIRA, Davi Alvez. Working memory capacity and mental translation in EFL reading comprehension. 2016. Dissertation (Master in Inglês) - Universidade Federal de Santa Catarina, Florianópolis, 2016. Available in: https:// repositorio.ufsc.br/handle/123456789/168075. Access in: July 13, 2018.

POSTLE, Bradley R. WM as an emergent property of the mind. Neuroscience, Washington, v. 139, n. 1, p. 23-38, Apr. 2006. Available in: https:/www.ncbi.nlm.nih.gov/pmc/ articles/PMC1428794/. Access in: July 25, 2018. https://doi. org/10.1016/j.neuroscience.2005.06.005

PROCAILO, Leonilda. Reading digital texts in L2 working memory capacity, text mode, and reading condition accounting for differences in processes and products of reading. Thesis (Doctorate in Inglês) - Universidade Federal de Santa Catarina, Florianópolis, 2017. Available in: https:// repositorio.ufsc.br/handle/123456789/187261. Access in: Aug. 27, 2018.

RUMELHART, David E. Schemata: the building blocks of cognition. In: SPIRO, Rand J.; BRUCE, Bertram C.; BREWER, William F. (ed.). Theoretical issues in reading and comprehension. Hillsdale: Routledge, 1980. p. 33-58. https://doi.org/10.4324/9781315107493-4

RUMELHART, David E. Understanding understanding. In: FLOOD, James (ed.). Understanding reading comprehension. Newark: International Reading Association, 1984.

RUMELHART, David E.; MCCLELLAND, J. L. Interactive processing through spreading activation. In: PERFETTI, C.; LESGOLD, A. (ed.). Interactive processes in reading. Hillsdale: [s. n.], 1981.

SEARLEMAN, Alan; HERRMANN, Douglas. Memory from a broader perspective. Singapore: McGraw-Hill College, 1994.

SPARKS, Richard L. Individual differences in L2 learning and long-term L1-L2 relationships. Language Learning, Michigan, v. 62, n. 2, p. 5-27, Aug. 2012. Available in: https://onlinelibrary.wiley.com/doi/full/10.1111/j.14679922.2012.00704.x. Access in: July 12, 2018. https://doi. org/10.1111/j.1467-9922.2012.00704.x

TOMITCH, Leda Maria Braga. Memorial de atividades acadêmicas. Memorial apresentado ao Departamento de Língua e Literatura Estrangeiras da Universidade Federal de Santa Catarina como requisito parcial para inscrição ao Concurso de Professor Titular da Carreira do Magistério Superior. Florianópolis: UFSC, 2014.

TOMITCH, Leda Maria Braga. Reading: text organization perception and working memory capacity. 1995. Thesis (Doctorade in Linguística Aplicada) - Universidade Federal de Santa Catarina, Florianópolis, 1995. Available in: https://repositorio.ufsc.br/handle/123456789/157902. Access in: Dec. 14, 2017.
TREVISOL, Juliane Regina; TOMITCH, Lêda Maria Braga. The relationship between bilingualism and working memory: a review. Revista do GELNE, Natal, v. 19, n. 1, p.39-51, 2017. Available in: https://periodicos.ufrn.br/gelne/article/ view/11263. Access in: June 26, 2018.

VAN DEN BROEK, Paul et al. The effects of readers' goals on inference generation and memory for texts. Memory \& Cognition, New York, v. 29, n. 8, p. 1081-1087, Dec. 2001. Available in: https://link.springer.com/article/10.3758/ BF03206376. Access in: Jan. 20, 2018. https://doi.org/ $10.3758 / \mathrm{BF} 03206376$

VEENMAN, M. V. J. Metacognition. In: AFFLERBACH, Peer. Handbook of individual differences in reading: reader, text, and context. Palo Alto: Routledge, 2015.

WOELFER, Sidenei Werner. Constructing meaning from cartoons: the effects of EFL reading proficiency and working memory capacity on the processing of verbal and pictorial information. 2016. Dissertation (Master in Inglês) - Universidade Federal de Santa Catarina, Florianópolis, 2016. Available in: https://repositorio.ufsc.br/ handle/123456789/167472. Access in: Mar. 13, 2018.

ZWAAN, Rolf A.; BROWN, Carol M. The influence of language proficiency and comprehension skill on situationmodel construction. Discourse Processes, Washington, v. 21, n. 3, p. 289-327, May/June 1996. Available in: https://eric. ed.gov/?id=EJ525861. Access in: Aug. 14, 2018. https://doi. org/10.1080/01638539609544960

Recebido em: 24/10/2018

Aprovado em: 12/6/2019.

Publicado em: 5/11/2019.

\section{Autores:}

SIDNEI WERNER WOELFER

Doutorando em Inglês/Estudos da Linguagem no Programa de Pós-Graduação em Inglês da Universidade Federal de Santa Catarina (UFSC).

Orcid: https://orcid.org/0000-0003-4707-5037

E-mail: sidnei.ww@gmail.com

LÊDa Maria Braga TOMitch

Doutorado em Letras pela UFSC. É professora titular do Departamento de Língua e Literatura Estrangeiras da Universidade Federal de Santa Catarina (UFSC).

Orcid: https://orcid.org/0000-0003-4183-8072

E-mail: leda@cce.ufsc.br

Endereço: Universidade Federal de Santa Catarina

Rua Eng. Agronômico Andrei Cristian Ferreira, s/n. - Trindade 88040-900, Florianópolis, SC, Brasil

LeONILDA Procailo

Doutora em Estudos da Linguagem pelo Programa de Pós-Graduação em Inglês da Universidade Federal de Santa Catarina (UFSC).

Professora da Universidade Estadual do Centro-Oeste (UNICENTRO), Guarapuava, PR, Brasil.

Orcid: https://orcid.org/0000-0003-0072-1214

E-mail:1procailo@gmail.com

Endereço: Universidade Estadual do Centro-Oeste

Rua Salvatore Renna, 875 - Santa Cruz

85015-430, Guarapuava, PR, Brasil 